\title{
Correlations Among Body Condition Scores from Various Sources, Dairy Form, and Cow Health from the United States and Denmark
}

\author{
C. D. Dechow, ${ }^{1, \star}$ G. W. Rogers, ${ }^{1}$ U. Sander-Nielsen, ${ }^{2}$ L. $\mathrm{Klei}{ }^{3}$ \\ T. J. Lawlor, ${ }^{3}$ J. S. Clay, ${ }^{4}$ A. E. Freeman, ${ }^{5}$ G. Abdel-Azim, ${ }^{6}$ \\ A. Kuck, ${ }^{6}$ and S. Schnell ${ }^{6}$ \\ ${ }^{1}$ Department of Animal Science, University of Tennessee, \\ 2640 Morgan Circle Drive, Knoxville 37996 \\ 2Danish Agricultural Advisory Center, Udkaersdej 15, Aarhus, Denmark 8200 \\ ${ }^{3}$ Holstein Association USA Inc., 1 Holstein Place, Brattleboro, VT 05302 \\ ${ }^{4}$ Dairy Record Management Systems, 313 Chapanoke Road, \\ Suite 100, Raleigh, NC 27603 \\ ${ }^{5}$ Department of Animal Science, lowa State University, Ames 50011 \\ ${ }^{6}$ Genex Cooperative, Inc., 100 MBC Drive, Shawano, WI 54166
}

\section{ABSTRACT}

The objectives of this study were to estimate genetic correlations among body condition scores (BCS) from various sources, dairy form, and measures of cow health. Body condition score and dairy form evaluated during routine type appraisal was obtained from the Holstein Association USA, Inc. A second set of BCS was obtained from Dairy Records Managements Systems (DRMS) and was recorded by producers that use PCDART dairy management software. Disease observations were obtained from recorded veterinarian treatments in several dairy herds in the United States. Estimated breeding values for diseases in Denmark were also obtained. Genetic correlations among BCS, dairy form, and cow health traits in the United States were generated with sire models. Models included fixed effects for age, DIM, and contemporary group. Random effects included sire, permanent environment, herd-year season for health traits, and error. Predicted transmitting abilities (PTA) for BCS and dairy form were correlated with estimated breeding values for disease in Denmark. The genetic correlation estimate between BCS from DRMS and BCS from the Holstein Association USA, Inc., was 0.85. The genetic correlation estimate between BCS and a composite of all diseases in the United States was -0.79 , and PTA for BCS was favorably correlated with an index of resistance to disease other than mastitis in Denmark (0.27). Dairy form was positively correlated with a composite of all diseases in the United States (0.85)

Received September 15, 2003.

Accepted March 27, 2004.

Corresponding author: C. D. Dechow; e-mail: cdd1@psu.edu.

*Current address: Department of Dairy and Animal Science, The Pennsylvania State University, 324 Henning Building, University Park, PA 16802. and was unfavorably correlated with an index for resistance to disease other than mastitis in Denmark $(-0.29)$. Adjustment for protein yield PTA had a minimal affect on correlations between PTA for BCS or dairy form and disease in Denmark. Selection for higher body condition or lower dairy form with continued selection for yield may slow deterioration in cow health as a correlated response to selection for increased yield.

(Key words: body condition score, dairy form, disease)

Abbreviation key: $\mathbf{A D}=$ all diseases, $\mathbf{B C S}_{\mathbf{D R M S}}=$ body condition scores from Dairy Records Management Systems, $\mathbf{B C S}_{\mathrm{HOL}}=$ body condition scores from Holstein Association USA, Inc., DA = displaced abomasum, $\mathbf{D O M}=$ diseases other than mastitis, $\mathbf{D R M S}=$ Dairy Records Management Systems, FLD = foot and leg diseases, $\mathbf{M D D}_{\mathbf{D M}}=$ metabolic and digestive diseases recorded in Denmark, $\mathbf{M D D}_{\mathbf{U S}}=$ metabolic and digestive diseases recorded in the United States, PTAB = predicted transmitting ability for body condition score, PTAD = predicted transmitting ability for dairy form, PTAP = predicted transmitting ability for protein yield.

\section{INTRODUCTION}

Selection for increased milk, fat, and protein yield has been very successful in the past, but has led to unfavorable correlated changes in incidence of metritis, ketosis, milk fever, cystic ovaries, lameness, mastitis, and other diseases (Tveit et al., 1992; Pösö and Mäntysaari, 1996; Van Dorp et al., 1998; Kadarmideen et al., 2000). There also appears to be less culling on the basis of low production and more involuntary culling compared with a decade ago (Weigel et al., 2003). Much of this shift toward higher levels of involuntary culling is likely due to poorer cow health and reproductive 
performance. Failure to conceive, milk fever, displaced abomasum, ketosis, and mastitis were all shown to increase the risk of culling even when the phenotypic affect of disease on milk yield was considered (Gröhn et al., 1998). Selection for resistance to disease has proven effective in countries with national diseaserecording schemes (Heringstad et al., 2000; Philipsson and Lindhé, 2003). No such recording scheme exists in the United States at this time.

Body condition scores may be an effective indicator trait for selection to reduce disease incidence in the United States. Change in body condition is an indicator of the energy status of a cow (Wildman et al., 1982). Milk yield is genetically correlated with an increase in early lactation body condition loss (Berry et al., 2002; Dechow et al., 2002) and negative energy balance (Harrison et al., 1990). Negative energy balance is associated with increased levels of ketosis, fatty liver, displaced abomasums and other metabolic disorders, laminitis, and other locomotive problems (Baird, 1982; Goff and Horst, 1997; Collard et al., 2000).

Genetic correlations between dairy form and BCS were reported to be -0.72 in the United States (Dechow et al., 2003), and genetic correlations between BCS and dairy character were reported to be -0.61 in Denmark (Lassen et al., 2003), indicating that high dairy form scores are associated with low body condition. Bulls that sire daughters with high dairy form in the United States had daughters that were more susceptible to metabolic, reproductive, and foot and leg diseases in Scandinavia (Rogers et al., 1999). Higher dairy character and lower body condition are also genetically correlated with more mastitis and diseases other than mastitis (DOM) in Denmark (Hansen et al., 2002; Lassen et al., 2003). Dairy form or BCS could be used in multiple-trait selection programs to help predict breeding values for health traits (Lassen et al., 2003).

Studies reporting the phenotypic relationship between cow health and body condition have used BCS recorded by producers or researchers. Genetic evaluations for BCS in the United States would likely come from a large, national recording scheme. The genetic relationship between BCS recorded by producers and BCS recorded as part of a national recording scheme has not been reported.

Previous studies reported heritability estimates for BCS and the relationship among BCS, type traits, and cow reproductive performance. The objective of this study was to investigate the genetic relationship among BCS, dairy form, and cow health measured in the United States and Denmark. A second objective was to investigate the genetic relationship between BCS that had been recorded by producers or herd con- sultants and BCS recorded in a large, national recording scheme during linear type appraisals.

\section{MATERIALS AND METHODS}

Body condition scores $\left(\mathbf{B C S}_{\mathbf{H O L}}\right)$ and dairy forms recorded on 613,338 cows $(728,597$ total records) from October 1997 through June 2000 were obtained from the Holstein Association USA, Inc. Body condition scores were recorded on a scale of 1 (thin) to 50 (fat). A minimum of 15 daughters per sire and 10 cows per herd-classification visit were required, and records from cows evaluated after 335 DIM, before 24 mo of age, or after 60 mo of age were eliminated. Second and later lactation records were only retained if records from all prior lactations were available. Body condition score was first recorded by Holstein classifiers in October 1997. However, many classifiers that were scoring cows for all other linear classification traits did not actively score body condition during the initial stages of BCS recording. Those classifiers generally set all BCS to a single arbitrary score, resulting in high frequencies of cows with a single score for some classifiers. Records from those classifiers were eliminated using the same procedures as Dechow et al. (2003). The edited data set contained 168,118 records from 155,550 cows. A second data set was formed with identical edits, except records from classifiers that abnormally scored body condition were retained to determine the affect of classifier edits. This second set included 375,657 records from 335,148 cows.

A second set of 134,542 BCS records (BCS DRMS $_{\text {D }}$ ) was obtained from Dairy Records Management Systems (DRMS) in Raleigh, NC, and was recorded on a scale of 1 (thin) to 5 (fat). Body condition scores were recorded from 1990 through September 1998. Producers and herd-consultants recorded BCS $\mathrm{BRMS}_{\mathrm{DR}}$ observations. Body condition scores from DRMS were recorded in one of 6 scoring periods: at calving, postpartum, first service, pregnancy check, before dry-off, and at dryoff. Days in milk when BCS DRMS $_{\text {was }}$ recorded was not available. Body condition scores from each scoring period were considered a separate trait, and heritabilities and correlations among $\mathrm{BCS}_{\mathrm{DRMS}}$ at all 6 scoring periods were reported by Dechow et al. (2001). Genetic correlations among the scoring periods were high, and BCS $_{\text {DRMS }}$ from all scoring periods were considered the same trait in this study. Body condition scores were retained from cows that had calved between 20 and 60 mo of age (age when BCS was assigned was not known). A minimum of 15 daughters per sire and 10 cows per contemporary group were required. Second (and later) lactation records were only retained if firstlactation records were available. This requirement 
eliminated all records from third lactation due to the short window of BCS recording in these herds. The edited $\mathrm{BCS}_{\mathrm{DRMS}}$ data set contained 44,190 records from 14,724 cows that were sired by 212 bulls, 185 of which had daughters with $\mathrm{BCS}_{\mathrm{HOL}}$.

Cow health data from the United States were obtained from a Genex Cooperative, Inc., progeny test study. Disease treatments were recorded from August 1994 through 1999 in herds with one or more daughters of 54 progeny test bulls that had been measured for immune function (Nash et al., 2000). Observations for the following diseases were retained: displaced abomasum (DA), acidosis, bloat, cecal torsion, diarrhea, fatty liver, ketosis, milk fever, foot abscesses, foot rot, laminitis, mastitis, cystic ovaries, retained placenta, and uterine infection. Cows with a disease treatment recorded $14 \mathrm{~d}$ before calving and up to 150 DIM were considered diseased (1), whereas cows without a disease treatment were considered nondiseased (0). Analyses for individual diseases were conducted only for those diseases with a frequency greater than $1 \%$.

Composite disease traits $(1=$ diseased, $0=$ not diseased) were formed that contained similar definitions to composite disease traits in Denmark (Danish Cattle Federation, 2002). Composite traits were metabolic and digestive diseases (MDD Us: DA, acidosis, bloat, cecal torsion, diarrhea, fatty liver, ketosis, and milk fever), reproductive diseases (cystic ovaries, retained placenta, and uterine infection), and a composite of all disease (AD). Cows that had calved between 20 and 60 mo of age were retained. Cows that had calved in the same herd-year season as one or more cows with a disease treatment of any of the disease traits were assumed to be disease free, and a minimum of 5 cows per herd-year season was required. Records from herdyear seasons with no disease treatments recorded were eliminated. Only 66 cows had disease recorded in multiple lactations. Retaining second and higher lactation records only from those cows with first-lactation data would have eliminated $42 \%$ of the disease records. One record per cow (first lactation available) was kept to avoid computation problems associated with permanent environment effects for disease traits, while retaining as many records as possible. The edited US health data set contained records on 8066 cows from 1313 sires, 417 of which had daughters with classification records. The data included 4559 first lactation, 2273 second lactation, and 1234 third and higher lactation records.

Body condition scores and dairy form from the Holstein Association USA, Inc., were merged with $\mathrm{BCS}_{\mathrm{DRMS}}$ and US health data. For cows with multiple $\mathrm{BCS}_{\mathrm{DRMS}}$ records in a given lactation, $\mathrm{BCS}_{\mathrm{HOL}}$ was merged with the BCS $\mathrm{BRMS}_{\text {DR }}$ scoring period correspond- ing to the DIM when $\mathrm{BCS}_{\mathrm{HOL}}$ was assigned. There was minimal overlap between the data sets. A total of 235 cows had both $\mathrm{BCS}_{\mathrm{HOL}}$ and US health data, and 151 cows had both $\mathrm{BCS}_{\mathrm{HOL}}$ and $\mathrm{BCS}_{\text {DRMS }}$.

Correlations among $\mathrm{BCS}_{\mathrm{HOL}}$, dairy form, $\mathrm{BCS}_{\mathrm{DRMS}}$, and US health were generated with 3 trait-sire models using ASREML (Gilmour et al., 2002). The statistical model used for the analysis was as follows:

$$
\mathbf{y}=\boldsymbol{X} \boldsymbol{\beta}+\mathbf{Z}_{1} \mathbf{s}+\mathbf{Z}_{2} \mathbf{p}+\mathbf{Z}_{3} \mathbf{c}+\varepsilon
$$

with $\mathbf{s} \sim\left(0, \sigma^{2} \mathrm{G}\right), \mathbf{p} \sim\left(0, \sigma^{2} \mathrm{I}_{1}\right), \mathbf{c} \sim\left(0, \sigma^{2} \mathrm{I}_{2}\right), \varepsilon \sim\left(0, \sigma^{2} \mathrm{R}\right)$, where $\mathbf{y}$ is a vector of $\mathrm{BCS}_{\mathrm{HOL}}$, dairy form, and either $\mathrm{BCS}_{\mathrm{DRMS}}$ or a US health trait; $\mathbf{X}$ is an incidence matrix for fixed effects; $\boldsymbol{\beta}$ is a vector of fixed effects; $\mathbf{Z}_{1}$ is an incidence matrix for sire effects; $\mathbf{s}$ is a vector of random sire effects; $\mathbf{Z}_{\mathbf{2}}$ is an incidence matrix for permanent environmental effects; $\boldsymbol{p}$ is a vector of random permanent environment effects; $\mathbf{Z}_{\mathbf{3}}$ is an incidence matrix for herdyear season effects, with zeros for BCS and dairy form observations; $\mathbf{c}$ is a vector of random contemporary group effects (for US health traits only); and $\varepsilon$ is a vector of random errors. The (co)variance matrix for genetic effects is $\mathbf{G}, \mathbf{I}_{1}$ is an identity matrix for permanent environmental effects, $\mathbf{I}_{2}$ is an identity matrix for herd-year season effects, and $\mathbf{R}$ is the residual (co)variance matrix.

Contemporary groups for US health traits were small and were treated as random effects to minimize loss of information. Contemporary groups were larger for BCS and dairy form and were treated as fixed effects. Contemporary groups were herd-classification visit for $\mathrm{BCS}_{\mathrm{HOL}}$ and dairy form and herd-year season of calving for US health. Contemporaries for $\mathrm{BCS}_{\mathrm{DRMS}}$ were cows that had calved in the same herd, year, and season and that had $\mathrm{BCS}_{\mathrm{DRMS}}$ recorded in the same scoring period and lactation. Seasons of calving for US health and $\mathrm{BCS}_{\mathrm{DRMS}}$ were defined as January through April, May through August, and September through December. Three generations of sire and dam were traced for all sires and relationships included in G. Additional covariates were second-order polynomials of age at calving (health traits and $\mathrm{BCS}_{\mathrm{DRMS}}$ ) or age at scoring (dairy form and $\mathrm{BCS}_{\mathrm{HOL}}$ ) nested within lactation for all traits and fifth-order polynomials of DIM nested within lactation for $\mathrm{BCS}_{\mathrm{HOL}}$ and dairy form.

Estimated breeding values for metabolic and digestive diseases $\left(\mathbf{M D D}_{\mathbf{D M}}\right)$, reproductive diseases, foot and leg diseases (FLD) in first, second, and third lactations in Denmark for 99 bulls that also have daughters with $\mathrm{BCS}_{\mathrm{HOL}}$, and dairy form observations in the United States were obtained from the Danish Agricultural Advisory Center (Aarhus, Denmark). An index of DOM was also obtained. A description of the dis- 
Table 1. Heritabilities (diagonal), genetic (above diagonal), and phenotypic (below diagonal) correlations among body condition score (BCS) from the Holstein Association USA, Inc. $\left(\mathrm{BCS}_{\mathrm{HOL}}\right)$, BCS from DRMS (BCS DRMS $_{\text {), and dairy form. }}{ }^{1}$

\begin{tabular}{lccc}
\hline & BCS $_{\text {HOL }}$ & Dairy form & BCS $_{\text {DRMS }}$ \\
\hline BCS $_{\text {HOL }}$ & 0.21 & -0.74 & 0.85 \\
Dairy form & -0.45 & 0.23 & -0.69 \\
BCS & 0.11 & -0.11 & 0.14 \\
\hline
\end{tabular}

${ }^{1}$ Standard errors of the heritability estimates ranged from 0.01 to 0.02 . Standard errors of the genetic correlation estimates range from 0.02 to 0.06 , and standard errors of the phenotypic correlation estimates range from 0.002 to 0.06 .

eases and procedures used to generate the estimated breeding values and health index are described in "Principles of Danish Cattle Breeding" (Danish Cattle Federation, 2002). For $\mathrm{MDD}_{\mathrm{DM}}, \mathrm{FLD}$, and reproductive diseases, a higher value represents a higher disease incidence. A higher value for DOM represents more resistance to disease (favorable), and the average for DOM is set to 100 with a standard deviation of 5 .

Predicted transmitting abilities for $\mathrm{BCS}_{\mathrm{HOL}}$ (PTAB) and dairy form (PTAD) were generated in ASREML with the Holstein data. Sire PTA for PTAB and PTAD were merged with estimated breeding values for disease in Denmark. Only sires with a minimum reliability $\left(\mathrm{r}_{\mathrm{ia}}^{2}\right)$ of 0.50 for $\mathrm{BCS}_{\mathrm{HOL}}$ and DOM were used. A total of 65 sires met minimum reliability requirements. Official sire evaluations for protein yield (PTAP) in the United States (from AIPL-USDA, Beltsville, MD) were also attained for all sires to adjust correlations for yield.

Estimated breeding values for disease in Denmark and PTAB and PTAD from the United States were correlated. Correlations between EBV among traits generated from daughter records in different countries would be expected to result from genetic ties between the 2 populations only and should not be biased by shared environments among the daughter groups.

\section{RESULTS AND DISCUSSION}

\section{Body Condition Score}

Heritabilities and correlations among $\mathrm{BCS}_{\mathrm{HOL}}$, BCS $_{\text {DRMS }}$, and dairy form are given in Table 1 . The heritability estimate of $\mathrm{BCS}_{\mathrm{DRMS}}$ was 0.14 . Dechow et al. (2001) reported heritabilities ranging from 0.07 to 0.20 when BCS from this data set were considered a separate trait for each scoring period in lactations 1 through 3 . The heritability estimate for $\mathrm{BCS}_{\mathrm{HOL}}$ was 0.21 and for dairy form was 0.23 , which are nearly identical to heritability estimates reported by Dechow et al. (2003) using this data set with different edits
Table 2. Frequency, heritability estimate from linear model $\left(\mathrm{h}_{\mathrm{B}}^{2}\right)$, and heritability estimate transformed to the continuous normal scale $\left(\mathrm{h}_{\mathrm{T}}^{2}\right)$ of displaced abomasum (DA), metabolic and digestive disease (MDD ${ }_{\text {US }}$ ), cystic ovaries (Cyst), all reproductive diseases (Repro), mastitis, and all disease (AD) from selected US dairy herds. ${ }^{1}$

\begin{tabular}{llcl}
\hline & \multicolumn{3}{c}{ All lactations } \\
\cline { 2 - 4 } Disease & freq & $\mathrm{h}_{\mathrm{B}}^{2}$ & $\mathrm{~h}_{\mathrm{T}}^{2}$ \\
\hline $\mathrm{DA}$ & 0.017 & 0.08 & 0.77 \\
MDD $_{\mathrm{US}}$ & 0.027 & 0.06 & 0.40 \\
Cyst & 0.020 & 0.02 & 0.17 \\
Repro & 0.056 & 0.00 & 0.02 \\
Mastitis & 0.060 & 0.02 & 0.06 \\
$\mathrm{AD}$ & 0.140 & 0.01 & 0.03 \\
\hline
\end{tabular}

${ }^{1}$ Standard errors of the $\mathrm{h}_{\mathrm{B}}^{2}$ estimates range from 0.01 to 0.03 .

for DIM. Repeatability estimates were 0.29 for $\mathrm{BCS}_{\mathrm{HOL}}, 0.56$ for dairy form, and 0.32 for $\mathrm{BCS}_{\mathrm{DRMS}}$.

The genetic correlation between $\mathrm{BCS}_{\mathrm{HOL}}$ and $\mathrm{BCS}_{\mathrm{DRMS}}$ was estimated to be 0.85 . Genetic correlations between dairy form and $\mathrm{BCS}_{\mathrm{HOL}}$ and $\mathrm{BCS}_{\mathrm{DRMS}}$ were -0.74 and -0.69 , respectively. As expected, $\mathrm{BCS}_{\mathrm{HOL}}$ and $\mathrm{BCS}_{\mathrm{DRMS}}$ appear to be very similar traits genetically even though observations for $\mathrm{BCS}_{\mathrm{HOL}}$ and $\mathrm{BCS}_{\mathrm{DRMS}}$ are recorded on a different scale and come from different evaluation systems. Cows that have high BCS measured on the 2 scales investigated are also genetically inclined to have lower dairy form scores. Higher BCS was also reported to be correlated with lower dairy character $(-0.61)$ in Denmark (Lassen et al., 2003). Selection for lower body condition or higher dairy form using PTA from national genetic evaluations will result in lower body condition, as recorded on farms.

The genetic correlation estimate between $\mathrm{BCS}_{\mathrm{HOL}}$ and $\mathrm{BCS}_{\mathrm{DRMS}}$ was 0.79 , and the heritability of $\mathrm{BCS}_{\mathrm{HOL}}$ was 0.16 when data not edited for classifier were used. The genetic correlation between dairy form and $\mathrm{BCS}_{\text {DRMS }}$ was -0.67 . The lower genetic correlation estimate between $\mathrm{BCS}_{\mathrm{HOL}}$ and $\mathrm{BCS}_{\mathrm{DRMS}}$ and lower heritability estimate for $\mathrm{BCS}_{\mathrm{HOL}}$ indicates that the classifier edits removed data from classifiers that were scoring body condition inaccurately. The edits did not change the genetic relationship between $\mathrm{BCS}_{\mathrm{DRMS}}$ and dairy form.

\section{US Health Data}

Disease frequencies and heritability estimates of diseases are given in Table 2. Disease frequencies ranged from $1.7 \%$ for DA to $6.0 \%$ for mastitis. All disease traits not included in Table 1 had frequencies less than $1 \%$. Disease frequencies were lower than many published estimates of the frequency of cow diseases and likely underestimate the frequency of cow 
Table 3. Genetic correlation estimates (standard errors) between body condition score $\left(\mathrm{BCS}_{\mathrm{HOL}}\right)$, dairy form and displaced abomasum (DA), metabolic and digestive disease ( $\mathrm{MDD}_{\mathrm{US}}$ ), cystic ovaries (Cyst), all reproductive diseases (Repro), mastitis, and all diseases (AD) from selected US dairy herds.

\begin{tabular}{lrr}
\hline & \multicolumn{1}{l}{ BCS $_{\text {HOL }}$} & Dairy form \\
\hline DA & $-0.48(0.15)$ & $0.54(0.15)$ \\
MDD & $-0.64(0.16)$ & $0.65(0.16)$ \\
Cyst & $0.13(0.28)$ & $-0.05(0.27)$ \\
Repro & $0.08(0.51)$ & $0.22(0.50)$ \\
Mastitis & $-0.93(0.27)$ & $0.60(0.26)$ \\
AD & $-0.79(0.31)$ & $0.85(0.31)$ \\
\hline
\end{tabular}

diseases (Lin et al., 1989; Gröhn et al., 1998; Collard et al., 2000; Heringstad et al., 2000). Because disease was recorded when a veterinarian treatment was required, many diseased cows not requiring treatment or cows treated by herd owners or managers likely went unreported.

Heritability estimates for disease traits on the observed linear scale ranged from 0.005 for reproductive diseases to 0.08 for DA. After transformation to the underlying liability scale (Dempster and Lerner, 1950), heritabilities ranged from 0.02 (reproductive diseases) to 0.77 (DA). Whereas low to moderate heritability estimates for such diseases have been reported, they are lower than the heritability estimates reported here. Previous heritability estimates were reported to range from 0.07 to 0.09 for ketosis (Mäntysaari et al., 1991), 0.09 to 0.42 for milk fever (Lin et al., 1989; Uribe et al., 1995), and 0.28 for DA (Uribe et al., 1995). The inflated heritability estimates and large standard errors in this study reflect the small sample size, combined with incomplete disease recording.

Genetic correlations between $\mathrm{BCS}_{\mathrm{HOL}}$, dairy form, and the disease traits are given in Table 3. Standard errors for the genetic correlations are large, ranging from 0.15 to 0.51 . Genetic correlation estimates among $\mathrm{BCS}_{\mathrm{HOL}}$ and $\mathrm{DA}, \mathrm{MDD}_{\mathrm{US}}$, mastitis, and $\mathrm{AD}$ were more than twice the standard error of the genetic correlation estimates, as were genetic correlation estimates between dairy form and the same traits. Higher dairy form scores were genetically correlated with higher disease incidence for all diseases except cystic ovaries $(-0.05)$, whereas higher $\mathrm{BCS}_{\mathrm{HOL}}$ was genetically correlated with less disease incidence for all diseases except cystic ovaries (0.13) and reproductive disease (0.08).

When using data that were not edited for classifier, the genetic correlation estimate between $\mathrm{AD}$ and $\mathrm{BCS}_{\mathrm{HOL}}$ was -0.28 and between $\mathrm{AD}$ and dairy form was 0.17 . The genetic correlation estimates were in the same direction but had reduced magnitude when inaccurate BCS was included.
Table 4. Correlations between estimated breeding value for disease traits in Denmark and predicted transmitting ability for BCS or dairy form in the US. ${ }^{1}$

\begin{tabular}{|c|c|c|c|c|c|c|}
\hline \multirow[b]{2}{*}{ Disease } & \multicolumn{2}{|c|}{ Lactation 1} & \multicolumn{2}{|c|}{ Lactation 2} & \multicolumn{2}{|c|}{ Lactation 3} \\
\hline & BCS & $\begin{array}{l}\text { Dairy } \\
\text { form }\end{array}$ & BCS & $\begin{array}{l}\text { Dairy } \\
\text { form }\end{array}$ & BCS & $\begin{array}{l}\text { Dairy } \\
\text { form }\end{array}$ \\
\hline Reproductive & -0.04 & 0.21 & -0.04 & 0.23 & -0.02 & 0.22 \\
\hline $\begin{array}{l}\text { Metabolic } \\
\text { and digestive }\end{array}$ & $-0.27^{*}$ & 0.22 & -0.20 & 0.09 & -0.22 & 0.08 \\
\hline Feet and leg & -0.25 & $0.40^{*}$ & -0.24 & $0.33^{*}$ & -0.24 & $0.31^{*}$ \\
\hline Mastitis $^{2}$ & $-0.25^{*}$ & $0.30^{*}$ & & & & \\
\hline $\mathrm{DOM}^{3}$ & $0.27^{*}$ & $-0.30 *$ & & & & \\
\hline
\end{tabular}

${ }^{1}$ Correlations have not been adjusted for reliability of the estimated breeding values.

${ }^{2}$ Mastitis evaluations were available for first lactation only.

${ }^{3} \mathrm{DOM}$ is an index of all diseases other than mastitis from lactations 1 through 3 .

$* P<0.05$.

\section{Disease in Denmark}

The average estimated breeding value for DOM of the 65 bulls that also had PTAB and PTAD was 97, with a minimum of 81 and a maximum of 110 . Correlations of estimated breeding values for disease in Denmark with PTAB and PTAD are reported in Table 4. These correlations would be expected to have a lower magnitude than the true genetic correlations because the breeding values for BCS, dairy form, and the disease traits are not known with certainty. Rogers et al. (1999) approximated genetic correlations from those among PTA for type traits in the United States and disease in Scandinavia by adjusting for reliability. This was not done here because our intent in generating these correlations was to corroborate the general direction of the genetic correlation estimates among BCS, dairy form, and US health traits.

Correlations between PTAB and MDD $_{\mathrm{DM}}, \mathrm{FLD}$, reproductive diseases, and mastitis were all negative, ranging from -0.02 to -0.27 . Correlation estimates were strongest between $\mathrm{BCS}_{\mathrm{HOL}}$ and $\mathrm{MDD}_{\mathrm{DM}}(-0.27$ to -0.20$)$ and mastitis $(-0.25)$. Correlations between $\mathrm{BCS}_{\mathrm{HOL}}$ and reproductive diseases were near $0(-0.04$ to -0.02). The correlation between $\mathrm{BCS}_{\mathrm{HOL}}$ and $\mathrm{DOM}$ was favorable (0.27).

Predicted transmitting abilities for dairy form were positively correlated with mastitis, reproductive disease, $\mathrm{MDD}_{\mathrm{DM}}$, and $\mathrm{FLD}$, ranging from 0.08 for $\mathrm{MDD}_{\mathrm{DM}}$ in lactation 3 to 0.40 for FLD in lactation 1. Dairy form was unfavorably correlated $(-0.30)$ with DOM.

When PTAB and PTAD were estimated with data that had not been edited for classifier, the correlation between PTAB and DOM was not as strong (0.17), whereas the correlation between dairy form and DOM was stronger $(-0.34)$. The reduced correlation between 
$\mathrm{BCS}_{\mathrm{HOL}}$ and DOM reflects inaccurate BCS observations in the unedited dataset, whereas the stronger correlation between dairy form and DOM reflects a higher reliability for PTAD (0.89 vs. 0.87$)$ due to an increase in daughters per sire.

Adjustment for PTAP had a minimal affect on correlation estimates (not shown). All correlations significant before adjustment for PTAP remained significant after adjustment for PTAP. Rogers et al. (1999) reported genetic correlation estimates between dairy form in the United States and reproductive disease, FLD, and $\mathrm{MDD}_{\mathrm{DM}}$, that were significant after adjustment for yield. Genetic correlation estimates between dairy character and disease other than mastitis in Denmark was 0.41 before and 0.39 after adjustment for protein yield (Hansen et al., 2002). The relationship among BCS, dairy form, and disease does not appear to result entirely from differences in yield. Selection to increase yield and maintain current levels of body condition or dairy form should help limit unfavorable changes in levels of cow health while yields increase.

Genetic correlation estimates for US health are based on a relatively small data set and are associated with large standard errors. Correlations between dairy form and $\mathrm{BCS}_{\mathrm{HOL}}$ and disease in Denmark are based on a limited number of highly selected bulls that have been used worldwide. However, there are consistent patterns that indicate a relationship among dairy form, $\mathrm{BCS}_{\mathrm{HOL}}$, and cow health traits. Correlation estimates among dairy form, $\mathrm{BCS}_{\mathrm{HOL}}$, and US health or disease in Denmark indicate that, at a given level of production, cows genetically inclined to be thin (high dairy form and low body condition) have higher levels of disease, particularly metabolic and digestive diseases, foot and leg diseases, and mastitis. Correlations between BCS and reproductive diseases were not as strong, perhaps due to an unfavorable relationship between body condition and cystic ovaries.

The relationships among BCS, dairy form, and disease reported in this study are consistent with genetic correlations reported in other studies. Genetic correlation estimates between dairy form recorded in the United States and DOM in Denmark was reported to be 0.73 in first lactation and 0.60 in second lactation, whereas the genetic correlation estimate between US dairy form and DOM in Sweden was 0.46 in first lactation (Rogers et al., 1999). The genetic correlation between BCS and DOM was estimated to be -0.22 , and the genetic correlation between BCS and mastitis was estimated to be -0.16 in Danish Holsteins (Lassen et al., 2003). Genetic correlation estimates between dairy character and disease were stronger $(0.43$ for DOM and 0.27 for mastitis) than correlation estimates between BCS and disease (Lassen et al., 2003).
The relationship between dairy form, $\mathrm{BCS}_{\mathrm{HOL}}$, and metabolic and digestive diseases is likely due to differences in early lactation negative energy balance. Dry matter intake for early lactation cows is often inadequate to provide the energy required to support milk yield, resulting in negative energy balance. Severe negative energy balance and excessive body fat mobilization is associated with metabolic disease (Baird, 1982; Goff and Horst, 1997). Dechow et al. (2002) reported that cows genetically inclined to have higher BCS lose less body condition in early lactation. Cows genetically inclined to have higher BCS appear to maintain more body condition in early lactation and likely have less severe negative energy balance in early lactation, resulting in less metabolic disease.

Negative energy balance may also play a role in the relationship among BCS, dairy form, and FLD observed in this study and in Rogers et al. (1999). Negative energy balance was associated with an increase in locomotive disorders, including laminitis (Collard et al., 2000), and metabolic disease may predispose cows to laminitis (Nocek, 1997).

The relationship between dairy form, BCS, and foot and leg disease is not likely the result of higher incidences of metabolic disorders only. High dairy form and low body condition was unfavorably correlated with foot and leg conformation, which could predispose cows to more foot and leg disorders (Dechow et al., 2003). The genetic correlation between dairy form and rear legs side view was 0.35 , and the genetic correlation between dairy form and foot angle was -0.21 , indicating that cows with higher dairy form tend to have more set to their hock and slightly lower foot angles (Dechow et al., 2003).

Dairy form tended to be more strongly correlated with disease incidence than BCS in this study and in Lassen et al. (2003). It is not clear why dairy form would be more strongly correlated with disease than body condition. The relationship between BCS and body composition has been investigated. A correlation of 0.87 was reported between BCS and the total body fat percentage of slaughtered cows of various genotypes, including dairy cows (O'Mara et al., 1998). Domecq et al. (1995) regressed BCS on various ultrasound measurements of subcutaneous fat depth from the pelvic region of Holstein cows and reported $R^{2}$ values ranging from 0.36 to 0.65 , indicating that $\mathrm{BCS}$ accurately reflects variation in fat deposition among cows in the pelvic region.

The relationship between dairy form and body composition has not been well defined, however. It is possible that dairy form is more highly correlated with differences in total internal and external body fat than BCS, particularly through the front end and over the 
rib structure. Body condition scores are generally assigned based on a visual assessment of the pelvic region only, whereas dairy form is assigned based on a visual assessment of the rib structure and general angularity of the cow.

\section{CONCLUSIONS}

Body condition scores recorded by the Holstein Association USA, Inc., provide a large, central source of $\mathrm{BCS}$ that could be used to generate genetic evaluations for body condition. Body condition scores recorded by producers or herd consultants and during linear type appraisals were highly correlated genetically.

Low BCS and high dairy form were genetically correlated with an increase in metabolic disease and poorer cow health. Including a strong positive emphasis on dairy form in the calculation of final score may encourage indirect selection for cows that are less healthy. Redefining the ideal dairy form to an intermediate optimum would retain a positive emphasis in final score for those cows that appear to be high producing, but would help limit possible detrimental effects of selection for final score on cow health.

Genetic correlation estimates between cow health and dairy form were stronger than genetic correlation estimates between BCS and cow health in this study and others. It is not clear that genetic evaluations for body condition would provide valuable genetic information beyond current dairy form evaluations. However, producers may be less reluctant to select for higher body condition than for lower dairy form because dairy form is weighted positively in final score calculations.

\section{ACKNOWLEDGMENTS}

The authors thank the Holstein Association USA, Inc., Genex Cooperative, Inc., Department of Animal Science at Iowa State University, Danish Agricultural Advisory Center, and Dairy Record Management Systems for providing data. Appreciation is expressed to the Holstein Association USA, Inc., and to the National Milk Producers Federation for providing financial assistance.

\section{REFERENCES}

Baird, G. D. 1982. Primary ketosis in the high producing dairy cow: Clinical and subclinical disorders, treatment, prevention, and outlook. J. Dairy Sci. 65:1-10.

Berry, D. P., F. Buckley, P. Dillon, R. D. Evans, M. Rath, and R. F. Veerkamp. 2002. Genetic parameters for level and change of body condition score and body weight in dairy cows. J. Dairy Sci. 85:2030-2039.

Collard, B. L., P. J. Boettcher, J. C. Dekkers, D. Petitclerc, and L. R. Schaeffer. 2000. Relationships between energy balance and health traits of dairy cattle in early lactation. J. Dairy Sci. 83:2683-2690.

Danish Cattle Federation. 2002. Principles of Danish Cattle Breeding. Available at: http://www.lr.dk/kvaeg/diverse/principles.pdf. Accessed June 11, 2003.

Dechow, C. D., G. W. Rogers, and J. S. Clay. 2001. Heritabilities and correlations among body condition scores, production traits, and reproductive performance. J. Dairy Sci. 84:266-275.

Dechow, C. D., G. W. Rogers, and J. S. Clay. 2002. Heritability and correlations among body condition score loss, body condition score, production and reproductive performance. J. Dairy Sci. 85:3062-3070.

Dechow, C. D., G. W. Rogers, L. Klei, and T. J. Lawlor. 2003. Heritabilities and correlations among body condition score, dairy form and selected linear type traits. J. Dairy Sci. 86:2236-2242.

Dempster, E. R., and I. M. Lerner. 1950. Heritability of threshold characters. Genetics 35:212-236.

Domecq, J. J., A. L. Skidmore, J. W. Lloyd, and J. B. Kaneene. 1995. Validation of body condition scores with ultrasound measurements of subcutaneous fat of dairy cows. J. Dairy Sci. 78:2308-2313.

Gilmour, A. R., B. R. Cullis, S. J. Welham, and R. Thompson. 2002. ASREML Reference Manual. ftp:ftp.res.bbsrc.ac.uk/pub/aar. Accessed February 3, 2003.

Goff, J. P., and R. L. Horst. 1997. Physiological changes at parturition and their relationship to metabolic disorders. J. Dairy Sci. 80:1260-1268.

Gröhn, Y. T., S. W. Eicker, V. Ducrocq, and J. A. Hertl. 1998. Effect of diseases on the culling of Holstein dairy cows in New York State. J. Dairy Sci. 81:966-978.

Hansen, M., M. S. Lund, M. K. Sorensen, and L. G. Christensen. 2002. Genetic parameters of dairy character, protein yield, clinical mastitis, and other diseases in the Danish Holstein cattle. J. Dairy Sci. 85:445-452.

Harrison, R. O., S. P. Ford, J. W. Young, A. J. Conley, and A. E. Freeman. 1990. Increased milk production versus reproductive and energy status of high producing dairy cows. J. Dairy Sci. 73:2749-2758.

Heringstad, B., G. Klemetsdal, and J. Ruane. 2000. Selection for mastitis resistance in dairy cattle: A review with focus on the situation in the Nordic countries. Livest. Prod. Sci. 64:95-106.

Kadarmideen, H. N., R. Thompson, and G. Simm. 2000. Linear and threshold model genetic parameters for disease, fertility and milk production in dairy cattle. Anim. Sci. 71:411-419.

Lassen, J., M. Hansen, M. K. Sørensen, G. P. Aamand, L. G. Christensen, and P. Madsen. 2003. Genetic relationship between body condition score, dairy character, mastitis, and diseases other than mastitis in first-parity Danish Holstein cows. J. Dairy Sci. 86:3730-3735.

Lin, H. K., P. A. Oltenacu, L. D. Van Vleck, H. N. Erb, and R. D. Smith. 1989. Heritabilities of and genetic correlations among six health problems in Holstein cows. J. Dairy Sci. 72:180-186.

Mäntysaari, E. A., Y. T. Gröhn, and R. L. Quaas. 1991. Clinical ketosis: Phenotypic and genetic correlations between occurrences and with milk yield. J. Dairy Sci. 74:3985-3993.

Nash, D. L., A. E. Freeman, A. L. Kuck, S. A. Schnell, and M. E. Kehrli. 2000. Relationships among calfhood diseases and sire transmitting abilities for measures of immune function. J. Dairy Sci. 78(Suppl. 1):75. (Abstr.)

Nocek, J. E. 1997. Bovine acidosis: Implications on laminitis. J. Dairy Sci. 80:1005-1028.

O’Mara, F. M., S. E. Williams, J. D. Tatum, G. G. Hilton, T. D. Pringle, J. W. Wise, and F. L. Williams. 1998. Prediction of slaughter cow composition using live animal and carcass traits. J. Anim. Sci. 76:1594-1603.

Philipsson, J., and B. Lindhé. 2003. Experiences of including reproduction and health traits in Scandinavian dairy cattle breeding programmes. Livest. Prod. Sci. 83:99-112.

Pösö, J., and E. A. Mäntysaari. 1996. Genetic relationships between reproductive disorders, operational days open and milk yield. Livest. Prod. Sci. 46:41-48. 
Rogers, G. W., G. Banos, and U. Sander-Nielsen. 1999. Genetic correlations among protein yield, productive life, and type traits from the United States and diseases other than mastitis from Denmark and Sweden. J. Dairy Sci. 82:1331-1338.

Tveit, F. L., M. Svendsen, and O. V. Sjaastad. 1992. Etiology of acetonemia in Norwegian cattle. 1. Effect of ketogenic silage, season, energy level, and genetic factors. J. Dairy Sci. 75:2421-2432.

Uribe, H. A., B. W. Kennedy, S. W. Martin, and D. F. Kelton. 1995. Genetic parameters for common health disorders of Holstein cows. J. Dairy Sci. 78:421-430.
Van Dorp, T. E., J. C. Dekkers, S. W. Martin, and J. P. Noordhuizen. 1998. Genetic parameters of health disorders, and relationships with 305-day milk yield and conformation traits of registered Holstein cows. J. Dairy Sci. 81:2264-2270.

Weigel, K. A., R. W. Palmer, and D. Z. Caraviello. 2003. Investigation of factors affecting voluntary and involuntary culling in expanding dairy herds in Wisconsin using survival analysis. J. Dairy Sci. 86:1482-1486.

Wildman, E. E., G. M. Jones, P. E. Wagner, R. L. Boman, H. F. Troutt, and T. N. Lesch, Jr. 1982. A dairy cow body condition scoring system and its relationship to selected production characteristics. J. Dairy Sci. 65:495-501. 